\title{
Центральное нагорье Вьетнама. Геополитическая оценка
}

\author{
Нгуен Данг Хой ${ }^{1 凶}$, Чыонг Куанг Хай² \\ ${ }^{1}$ Вьетнамско-Российский тропический центр, Соииалистическая Республика Вьетнам \\ (63 Нгуен Ван Хуен, Нгиа До, Кау Зяй, Ханой) \\ ${ }^{2}$ Ханойский государственный университет, Сочиалистическая Республика Вьетнам \\ (144 Суан Туи, Кау Зяй, Ханой)
}

\begin{abstract}
Аннотация: Цель: проанализировать основные аспекты, составляющие геополитическую позицию Центрального нагорья, его значение и влияние на экономическое развитие, укрепление национальной обороны и безопасности, управление природными ресурсами и окружающей средой.

Meтоды и материальы. Для геополитической оценки Центрального нагорья пользовались аналитическими методами опубликованных материалов. Геополитическая позиция Центрального нагорья определяется характеристиками геополитического пространства, геополитического региона и национальных пограничных районов с Лаосом и Камбоджей. Центральное нагорье тесно связано с окрестными районами, особенно с Южным центральным побережьем, для создания единства, способствующего укреплению его геополитической позиции не только во Вьетнаме, но и в Юго-Восточной Азии.

Результаты и обсуждение. Создание пространств связи межрегиона и эксрегиона, особенно связи в области управления ресурсами, распространения материалов - потоков продуктов, создания преемственного положения в области обороны - безопасности и культурного пространства - этнической группы являются основными и важными вопросами в экономическом развитии, укреплении национальной обороны и безопасности, а также в управлении природными ресурсами и окружающей средой этого региона. Это также повышает его значение геополитической позиции в XXI веке и далеко в будущем.

Заключение. На протяжении всей своей истории Центральное нагорье всегда занимало очень важную геополитическую позицию. Природные и этнические ценности с политическим контекстом создали незаменимые ценности Центрального нагорья на экономику, политику, национальную оборону безопасность, природные ресурсы и окружающую среду. Чтобы продвигать дальше ценность Центрального Нагорья, необходимо установить пространственные связи внутри и снаружи, установить преемственное положение в области обороны - безопасности и культурного пространства этнических групп.

Ключевые слова: этнические группы, Южное центральное побережье, область обороны, Центральное нагорье, геополитическая позиция.

Для цитирования: Нгуен Данг Хой, Чыонг Куанг Хай Центральное нагорье Вьетнама. Геополитическая оценка // Вестник Воронежского государственного университета. Серия: География. Геоэкология, 2020, № 2, с. 3-13. DOI: https://doi.org/10.17308/geo.2020.2/2879
\end{abstract}

\section{ВВЕДЕНИЕ}

Факты и теоретическая база доказывает, что жизненное пространство и природные ресурсы являются основными ценностями современного мира $[1,2,7,13]$. В таких науках, как геополитика, политическая география, науки о международных отношениях, территориальное положение является одним из основных, решающих факторов, определяющих многие проблемы каждой страны,

() Нгуен Данг Хой, Чыонг Куанг Хай, 2020

E-mail: danghoi110@gmail.com каждого региона [3, 5, 13]. Неслучайно Вьетнам стал страной, которую стремились завоевывать иностранные державы. За тысячи лет строительства и защиты страны нам пришлось вести десятки войн против внешних захватчиков $[11,14]$. Это объясняется положением страны в Индокитае и Азиатско-Тихоокеанском регионе.

Как страна с большим протяжением морской границы в Восточном море (Bien Dong), где проходит международный морской маршрут в самом

Контент доступен под лицензией Creative Commons Attribution 4.0 License. 
важном регионе мира с богатыми природными ресурсами, способствующими особому значению нашей страны $[10,14]$. Это касается не только естественного и экономического положения, но и геополитического положения страны. Такая позиция очень важна для судьбы и процветания Вьетнама и региона в целом $[12,19]$.

Центральное нагорье, наряду с Южным центральным побережьем (Central Coast), образует среднюю часть страны, тесно связанную с двумя ее соседями: Лаосом и Камбоджей. Оно играет особую роль в процессах индустриализации и модернизации страны, развития рыночной экономики на основе знаний, лесных и морских ресурсов. За прошедшее время, благодаря вниманию Коммунистической партии Вьетнама, значительным инвестициям государства, усилиям самой провинции, социально-экономическое положение Центрального нагорья значительно расширились.

Однако, комплексная эксплуатация природных ресурсов Центрального нагорья для социальноэкономического развития, укрепления национальной обороны и безопасности, управления природными ресурсами и окружающей средой по-прежнему ограничена. Координация и сотрудничество между провинциями, а также между Центральным нагорьем и прилегающими районами (включая провинции Лаоса и Камбоджи) еще неадекватны и иногда формальны. Потенциал положения Центрального нагорья не был полностью использован. Позиция провинции и всего региона в действительности не стали ни движущей силой, ни эффективным ресурсом для развития. Поэтому правильный анализ, выявление и прогнозирование позиции Центрального нагорья в настоящее время и на ближайшие годы очень важно, что имеет глубокие теоретические и практические значения.

\section{ТЕОРЕТИЧЕСКИЕ ПРОБЛЕМЫ И СУЩНОСТИ ГЕОПОЛИТИЧЕСКОЙ ПОЗИЦИИ}

До сих пор все еще существуют несогласованные концепции в определении содержания геополитической позиции $[3,5]$. Тем не менее, можно говорить о значении, ценности геополитической позиции региона, страны. Эта выгода связана с сочетанием естественно-гуманитарного географического преимущества в определенном контексте в сфере экономики и политики $[10,19]$. Исходя из составляющих компонентов и элементов, естественная геополитическая позиция Центрального нагорья очень стабильна, но экономическая стабильна на среднем уровне. Геополитическая по- зиция региона в целом часто имеет низкую стабильность. Она во многом зависит от внутреннего и внешнего политического контекста, от национального, регионального и международного положения [8]. При анализе и оценке геополитической позиции Центрального нагорья в экономическом развитии, укреплении национальной обороны и безопасности в управлении природными ресурсами и окружающей средой следует учитывать следующие факторы.

1. Геополитическое пространство. Географическое пространство и среда выражаются в виде факторов, влияющих на межрегиональные и международные отношения. На национальном уровне геополитическое пространство Центрального нагорья играет важную роль во внешней политике Вьетнама с Лаосом, Камбоджей и другими странами в Юго-восточной Азии.

2. Геополитический регион. Пространство характеризуется высокой интенсивностью политических, экономических, культурных, военных отношений. В конкретных исследованиях в Центральном нагорье, этот контент упоминается как взаимодействие, взаимовлияние друг на друга между культурой этнических народов (этнических групп), экономическими характеристиками, политическими системами провинций Центрального нагорья, между Центральным нагорьем и прибрежными провинциями, между Центральным нагорьем и Лаосом и Камбоджей. В таком случае необходимо решить следующие вопросы: положение, роль и функции Центрального нагорья во вьетнамском государстве в общем; положение, роль и функции Центрального нагорья в геополитическом регионе Юго-Восточной Азии; выделить важные региональные и межрегиональные проблемы; наметить систему решений и мер по укреплению ценностей Центрального нагорья и страны.

3. Национальная граница. Особое место страны, граничащей с другой страной или внешней границей территориального моря. Эта особенность показана разделительной линией территории и политического пространства в Центральном нагорье Вьетнама с Лаосом и Камбоджей в качестве национальной границы. При рассмотрении значения геополитической позиции Центрального нагорья, национальные границы рассматриваются на уровне пограничных зон или пограничных полос с достаточным пространством, содержащим природные и антропогенные компоненты для взаимосвязи и их взаимодействия друг на друга. 


\section{ОСНОВНЫЕ ХАРАКТЕРИСТИКИ ГЕОПОЛИТИЧЕСКОЙ ПОЗИЦИИ ЦЕНТРАЛЬНОГО НАГОРЬЯ ВЬЕТНАМА}

Центральное нагорье характеризуется гористой, холмистой местностью, чередующейся с широкими плато на относительно большой высоте. C севера горный массив Нгок Линь (Ngoc Linh) имеет высоту более 2000 м над уровнем моря (вершина Нгок Линь высотой 2598 м н. у. м.) до массивов Кон Ка Кинь (1761 м), Чу Зянг Син (2442 м), Бидуп (2287 м) формируют высокую часть в форме арки, обращенной к Восточному морю. Обладая заметной высотой по сравнению с окрестностью, включая нижний Лаос и северо-восточную Камбоджу, Центральное нагорье имеет особое положение и оказывает прямое влияние на Южное центральное побережье, Лаос и Камбоджу в большинстве аспектов: природном, экономико-политическом, оборонном и экологической безопасности, создает политическое пространство на региональном уровне.

Кроме того, явное расслоение по высоте на севере и востоке является основой для формирования системы перевалов на важных транспортных осях от центральных прибрежных провинций в Центральное нагорье. Согласно статистическим данным, от центральных прибрежных провинций до Центрального нагорья существует 7 важных перевалов, а именно: перевал Ло Co (Lo So) на национальной автомагистрали 14 из уезда Фыок Сон (Phuoc Son), провинция Куанг Нам в уезд Дак Глей (Dak Glei), провинция Кон Тум; перевал Вио Лак (Vio Lak) на национальной автомагистрали 24 из уезда Ба То (Ва То), провинция Куанг Нгай в уезд Кон Плонг (Kon Plong), провинция Кон Тум; перевал Ан Хе (An Khe) из уезда Таи Сон (Tay Son), провинция Бинь Динь в город Ан Хе, провинция Зя Лай; перевал Фыонг Хоанг (Phuong Hoang) на национальной автомагистрали 26 из уезда Нинь Хоа (Ninh Hoa), провинция Хань Хоа в уезд Ма Драк (M'Drak), провинция Дак Лак; перевал Хон Зао из уезда Хань Винь (Khanh Vinh), провинция Хань Хоа в уезд Лак Зыонг (Lac Duong), провинция Лам Донг на дороги 723; перевал Нгон Мук (Ngoan Muc) на национальной автомагистрали 27 из уезда Нинь Сон (Ninh Son), провинция Нинь Тхуан в уезд Дон Зыонг (Don Duong), провинция Лам Донг и перевал Зя Бак (Gia Bac), на национальной автомагистрали 28 из уезда Хам Тхуан Бак (Ham Thuan Bac), провинция Винь Тхуан в уезд Ди Линь (Di Linh), провинция Lam Dong. У каждого перевала есть свои особенности. Но общей чертой их является крутой, извилистый профиль, длиной в десятки километров и обычно только с одной стороны (кроме перевалов Ло Со и Вио Лак). Именно одна сторона перевалов создает «решающую» позицию Центрального нагорья в военном искусстве как в наступательном, так и в оборонительном.

Центральное нагорье является истоком многих рек, стекающих к центральному побережью, что является верховьем многих средних рек, впадающих в реку Меконг через территорию Лаоса и Камбоджи, создавая речные бассейны неотделимые друг от друга. В антропогенном аспекте, формирование международных пограничных ворот между провинциями Центрального нагорья с нижним Лаосом и северо-восточной Камбоджей. Соответственно, между провинцией Кон Тум и провинцией Аттапеу (Лаос) находится пограничная ворота Бо У; между провинцией Зя Лай и провинцией Ратанакири (Камбоджа) находятся пограничные ворота Ле Тхань; между провинцией Дак Нонг и провинцией Мондулкири (Камбоджа) находятся пограничные ворота Дак Пеер. Хотя число пограничных ворот невелико, а экономика пограничных ворот на самом деле не развита, только занимает незначительную долю в экономической структуре Центрального нагорья, но они наряду с другими природно-антропогенными факторами устанавливают тесные связи между природой, природными ресурсами и окружающей средой, а это является основой для интеграции и координации на национальном и межрегиональном уровнях в области управления природными ресурсами и их использования, особенно водных и лесных ресурсов, ресурсов биоразнообразия.

Из-за историко-географических условий этнические группы в Центральном нагорье имеют разный уровень формирования и развития, но у них общая характеристика - интеграция и привязанность к этой земле происходит быстро и глубоко. Согласно статистическим данным [18] к апрелю 2019 года население Центрального нагорья составляло около 5842,70 тыс. человек, средняя плотность по всему региону равна 106,8 человек/км ${ }^{2}$, где проживает более 30 этнических групп. В частности, плотность распределения населения по микрорегионам сильно отличается. На севере Центрального нагорья (Кон Тум, Зя Лай) и Дак Нонг (Юго-Запад Центрального нагорья) имеют низкую плотность населения - от 55 человек/км² в Кон Тум до более 102 человек/км² в Зя Лай. В провинциях Дак Лак и Лам Донг плотность населения выше - 
Численность населения и главные этнические группы провинций в Центральном нагорье [Table 1. Number of population and main ethnic groups of provinces in the Central Highlands]

\begin{tabular}{|c|l|c|c|c|}
\hline $\begin{array}{c}\text { № / } \\
\text { No. }\end{array}$ & $\begin{array}{c}\text { Провинции / } \\
\text { Provinces }\end{array}$ & $\begin{array}{c}\text { Численность } \\
\text { населения } \\
\text { (человек)/ } \\
\text { Population } \\
\text { (реople) }\end{array}$ & $\begin{array}{c}\text { Плотность } \\
\text { населения } \\
(\text { чел/км²)/ } \\
\text { Population } \\
\text { density } \\
\text { (people/km²) }\end{array}$ & $\begin{array}{c}\text { Основные } \\
\text { этнические группы / } \\
\text { Main ethnic groups }\end{array}$ \\
\hline 1 & Кон Тум & 540.438 & 55 & $\begin{array}{c}\text { Сэ Данг, Ба На, Дже Чйенг, } \\
\text { Зя Рай, Ро Мам }\end{array}$ \\
\hline 2 & Зя Лай & 1.513 .847 & 102 & Зя Рай, Ба На, Э Де \\
\hline 3 & Дак Лак & 1.869 .322 & 135 & Э Де, М’Нонг \\
\hline 4 & Дак Нонг & 622.168 & 96 & М'Нонг, Нунг, Ма \\
\hline 5 & Лам Донг & 1.296 .906 & 125 & Ко Хо, Ма, Чу Ру, Хо Ме \\
\hline
\end{tabular}

Источник: Генеральное главное статистическое управление Вьетнама, 2019 [17]

[Source: General main statistical office of Vietnam, 2019 [17]]

от 125 до 135 человек/км² (почти в 2,5 раза выше, чем в Кон Тум).

Результаты исследования показывают, что у каждой провинции - свое жизненное пространство определенных этнических групп. Это создает особенности по культуре, политике и духу. Соответственно, в провинциях на Севере Центрального нагорья проживают народы Се Данг, Ба На, Зя Рай ..., в провинциях на Юге проживают народы Э Де, М'нонг, Ко Хо ... (таблица 1). Характеристика распределения населения, культура - этническая группа в Центральном нагорье имеют большое значение для определения геополитической позиции этого района и каждой провинции.

Культура общинного дома - фестивали Конг Чйенг (Kong Trieng) переплетаются с культурами народов, пришедших в Центральное нагорье, чтобы исследовать и расширять, такие как Кинь, Х'Монг, Муонг, Зао и т. д. Кроме того, религия, как правило, католицизм, буддизм, протестантизм и Као Дай являются духовными факторами, влияющими на различные аспекты общественной жизни, включая национальную оборону, безопасность, экономику и окружающую среду $[16,17]$. Это создает взаимодействие, резонанс культуры, политики, составляет влияние на окрестные территории. Национальная граница не границы природы (как реки, водоразделы), а вместе с развитием транспортной системы по направлению Север - Юг, Восток - Запад, создает все большее влияние между Центральным нагорьем и соседними провинциями Лаоса и Камбоджи, а это влияет на почти все аспекты общественной жизни, особенно в приграничных уездах и городах. Это практическая осно- ва для создания пограничного района с сильным взаимодействием между Вьетнамом, Лаосом и Камбоджей через территорию Центрального нагорья.

Из аспекта военной обороны пространство Центрального нагорья является очень важным стратегическим районом как для региона южного Вьетнама (из г. Дананга), нижнего Лаоса, так и западной части Камбоджи. Чтобы лучше понять значение этого атрибута, его можно проанализировать в ходе войны против США, особенно во время кампании Хо Ши Мина. После того, как Политбюро Коммунистической партии Вьетнама решило освободить Юг Вьетнама в 1975 году, Постоянный комитет Центральной военной комиссии решил выбрать Центральное нагорье в качестве стартовой кампании, а стартовой ключевой битвой был Буон Ма Тхуат. Хотя Буон Ма Тхуат не является головным-штабом правительства Республики Вьетнам в Центральном нагорье, как Плейку (провинция Зя Лай), но это культурный и политический центр Центрального нагорья, центр Южного Вьетнама - нижнего Лаоса - западной Камбоджи (с точки зрения географии). Из Буон Ма Тхуат можно одновременно развернуть резервы во все стороны самым быстрым и удобным способом, особенно доступ к г. Нячангу и г. Хошимину. Более того, с использованием высотного рельефа и широкого пространства, созданным с окружающих областей, когда мы контролируем Буон Ма Тхуат, мы создаем плацдарм, быстро контролируем Север Центрального нагорья, создаем трамплин для нападения в Сай Гон - Зя Динь и на все центральное побережье $[15,16]$. Таким образом, благодаря точному определению позиции Южного централь- 
ного нагорья как основного направления, в котором Буон Ма Тхуат был ключевой целью нашей военной деятельности в конкретном контексте того времени, оно принесло победу для кампании «Тау Nguyen», которая быстро привела к победе исторической кампании «Но Chi Minh».

Уникальной особенностью является связь между Центральным нагорьем и окрестными районами в войне защиты Отечества. В антифранцузском периоде, особенно в войне против США, тесная связь между Центральным нагорьем и Южным центральным побережьем, а также Центральным нагорьем с Лаосом и Камбоджей играла решающую роль в создании сил, организации и борьбе с врагом, в транспорте войск и материально-техническом обеспечении. Во время войны сопротивления против США, в дополнение к очень ограниченной поддержке со стороны моря Донг (Восточного моря), создание и поддержание сопротивления в Центральном побережье всегда имело сильную и эффективную поддержку почти во всех аспектах из Центрального нагорья. Это было бы чрезвычайно сложно, если бы без взаимной помощи между провинциями Центрального нагорья и граничащими провинциями Лаоса и Камбоджи посредством передвижения сил, транспортных средств, оружия, технического оборудования и материально-технического обеспечения. Именно это составляет для Центрального нагорья геополитическую позицию по большинству аспектов, таких как: политическое пространство, политический регион и национальные границы, включая контент на национальную оборону - безопасность.

АНАЛИЗ ГЕОПОЛИТИЧЕСКОЙ ПОЗИЦИИ
ЦЕНТРАЛЬНОГО НАГОРЬЯ В
ЭКОНОМИЧЕСКОМ РАЗВИТИИ,
УКРЕПЛЕНИИ НАЦИОНАЛЬНОЙ ОБОРОНЫ
И БЕЗОПАСНОСТИ, УПРАВЛЕНИИ
ПРИРОДНЫМИ РЕСУРСАМИ И
ОКРУЖАЮЩЕЙ СРЕДОЙ

1. В экономическом развитии. С обширным пространством, богатыми природными ресурсами, в том числе лесными и водными, Центральное нагорье оказывает непосредственное влияние на прилегающие территории, такие как Южное центральное побережье, провинция Аттапеу (Нижний Лаос), провинции в Северо-Восточной Камбодже. Это является большим преимуществом для Центрального нагорья в развитии сельского хозяйства, лесного хозяйства, энергетики и ирригации на основе местных ресурсов. Относительно большие плато с удобными связями с Лаосом и Камбоджей являются возможностями для торговых и экономических связей развития между провинциями Центрального нагорья и граничащими провинциями соседних стран. Таких геополитических пространств больше нигде нет во Вьетнаме.

В последние годы, в связи с требованиями развития товарной экономики и необходимостью удовлетворения материальной и духовной жизни людей Центрального нагорья, взаимосвязь и взаимозависимость между Центральным нагорьем и регионом Центрального побережья становятся все более и более отчетливо видна через экономическую сферу. Это содержание выражается в создании центров производства и потребления с транспортировкой сырья, продуктов и производственных сил от Центрального побережья до Центрального нагорья и наоборот. Транспортная система сильно развивается не только вдоль осей Север Юг, таких как дорога Хо Ши Мина, дорога Чыонг Сон Донг, пограничные патрулирующие дороги (на суше), но также дороги в виде рыбных костей везде в направлении Восток - Запад, соединяющие Центральное нагорье с Центральным побережьем, а также с Лаосом и Камбоджей. Эти процессы также дополняются связью с другими соседними регионами и иностранными районами через систему международных пограничных ворот: Вьетнама - Лаоса, Вьетнама - Камбоджи и морские порты Центрального побережья, создавая торговую сеть и экономические связи не только в пределах Вьетнама и Индокитая, а также во всей Юго-Восточной Азии и других странах мира. Доказательством этой связи являются продуктовые потоки кофе, перца, готовых изделий из древесины и т. д. и многих других продуктов и оборудования, которыми обмениваются многомерным образом.

2. В сохранении и развитии культурно-исторических ценностей. Культурная близость этнических групп к окрестным районам (включая Лаос и Камбоджу), особенно в языковой группе МонХмер (Mon-Khomer) является преимуществом, созданным на основе человеческих ценностей Центрального нагорья. Это делает возможным сохранение и развитие культурных ценностей Центрального нагорья с прилегающими районами в целом более удобной.

Довольно легко это подтвердить при рассмотрении пространственного распределения этнических групп Центрального нагорья, Южного Центрального Побережья и Нижнего Лаоса. Такая 
скученность выражается смежным пространством между провинциями этих областей. При рассмотрении внутренних отношений Вьетнама между Центральным нагорьем и Южным Центральным Побережьем, за исключением некоторых этнических групп, жизненное пространство которых не слишком велико, географические данные о населении показывают, что между провинцией Кон Тум на западе и провинциями Куанг Нам и Куанг Нгай на востоке имеют пространственное распределение этнических групп Сэ Данг (Xe Dang) и Дже Триенг (Gie Trieng); между провинцией Зя Лай на западе и провинциями Бинь Динь, Фу Иен на востоке - жизненное пространство этнических групп Ба На и Э Де; между провинциями Южного Центрального нагорья и провинциями Южного Центрального Побережья, где распространены группы Ко Хо, Чу ру и т. д. Такое распределение этнических групп не только создает общее культурное пространство для двух регионов, но и формирует основу для организации административных единиц и взаимоотношений политического аппарата на всех уровнях для двух регионов, особенно уездных и общинных.

3. В обеспечении национальной обороны и безопасности. От неотъемлемых свойств естественной и гуманитарное географической ценности, сформировали геополитический незаменимый регион в обеспечении национальной обороны Вьетнама в долгой истории, особенно во время борьбы с французскими колонизаторами и американскими империалистами и в войне за защиту юго-западной границы в период 70-80-ых XX века и в укреплении национальной обороны и безопасности за последние десятилетия.

В связи с основной политикой Коммунистической партии и Государства Вьетнам в создании всенародной обороны, всенародной оборонительной позиции с позицией народной безопасности, в XXI веке и в будущем, Центральное нагорье будет определено в качестве ключевой области в создании оборонительной позиции от национального до уездного местного уровня. Раньше эта ценность Центрального нагорья была в основном обусловлена топографическими характеристиками, отчасти благодаря историческим обстоятельствам, тесной взаимосвязи трех индокитайских стран [9]. В будущем эти значения будут продолжать сохраняться с новыми признаками. Благодаря своей комплексной позиции, если защищаться от моря, Южное центральное побережье является фронтом, Центральное нагорье является тылом с твердой позицией вдоль хребта Чыонг Сон; если защищаться со стороны запада, тогда Центральное нагорье - фронт не только для Центрального побережья, но также для Юго-Восточных регионов страны. Благодаря сплоченности индокитайских стран, Центральное нагорье также играет роль прочного тыла и надежного тыла извне стран для Лаоса и Камбоджи.

Органическая сплоченность между Центральным нагорьем и Центральным побережьем создает устойчивую преемственность для межрегионального пространства, особенно в оборонительной позиции района, независимо от защиты с любого направления: с моря, с запада или с севера на юг, с юга на север. Преемственность и сплоченность Центрального нагорья и Южного центрального побережья отчетливо проявляются благодаря происхождению природных факторов, культурных ценностей и этнических групп. Об этом ясно свидетельствует сплоченность компонентов: рельеф, растительность, система речных бассейнов и этнические группы.

Благодаря стабильной политической системе, исходя из естественных преимуществ и отношений культуры и этнических групп, создается геополитическое пространство оборонного района Центрального нагорья. Это играет важную роль не только для центрального региона, но и Юго-Востока и немного дальше - Юго-Западный регион Вьетнама. Это выдающаяся ценность по национальной обороне и безопасности Центрального нагорья и Южного центрального побережья. Это значение не будет существовать или, если оно вообще существует, будет слабым, если только Центральное нагорье без Южного центрального побережья, или наоборот, только Южное центральное побережье без Центрального нагорья. Поэтому связь и объединение Центрального нагорья с Южным центральным побережьем больше не только являются целью, а становятся важным принципом социально-экономического развития, связанного с национальной обороной и безопасностью в XXI веке.

4. В управлении, использовании природных ресурсов и охране окружающей среды. При рассмотрении аспектов природных ресурсов и окружающей среды, когда упоминать Центральное нагорье, это значит говорить о лесных ресурсах, биоразнообразии, земельных и водных ресурсах. Центральное нагорье является одним из мировых центров биоразнообразия. С точки зрения ресурсов биоразнообразия Центральное нагорье имеет гло- 
Ресурсы биоразнообразия и глобальная природоохранная ценность высших растений и диких млекопитающих национальных парков Центрального нагорья

[Table 2. Biodiversity Resources and the Global Conservation Value of Higher Plants and Wild Mammals in Central Highlands National Parks]

\begin{tabular}{|c|c|c|c|c|c|c|c|c|c|}
\hline \multirow[b]{2}{*}{$\begin{array}{l}\text { № / } \\
\text { №. }\end{array}$} & \multirow[b]{2}{*}{$\begin{array}{c}\text { Название } \\
\text { национальног } \\
\text { о парка / } \\
\text { National Park } \\
\text { Name }\end{array}$} & \multicolumn{4}{|c|}{ Высшие растения / Higher plants } & \multicolumn{4}{|c|}{$\begin{array}{l}\text { Дикие млекопитающие / } \\
\text { Wild mammals }\end{array}$} \\
\hline & & 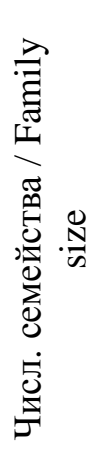 & 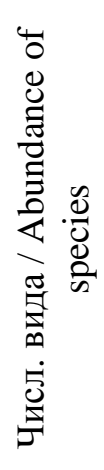 & 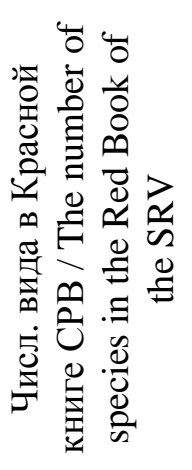 & 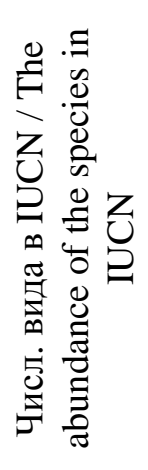 & 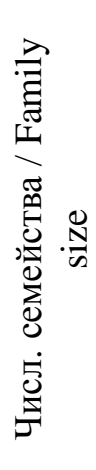 & 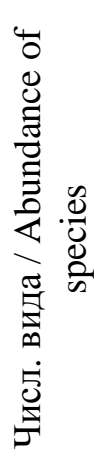 & 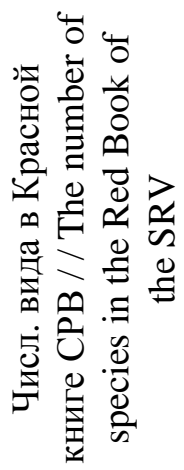 & 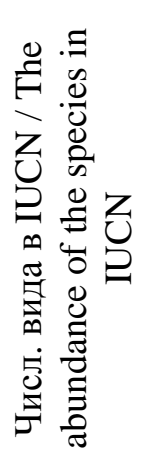 \\
\hline 1 & Чы Мом Раи & 184 & 1.895 & 49 & 65 & 28 & 120 & 35 & 43 \\
\hline 2 & Кон Ка Кинь & 168 & 1.022 & 28 & 17 & 25 & 76 & 24 & 21 \\
\hline 3 & Чы Зянг Син & 155 & 948 & 55 & 27 & 28 & 62 & 30 & 46 \\
\hline 4 & Иок Дон & 129 & 858 & 23 & 16 & 28 & 70 & 25 & 31 \\
\hline 5 & Бидуп - Нуйба & 180 & 1.944 & 73 & 132 & 28 & 111 & 38 & 70 \\
\hline
\end{tabular}

Источник: Нгуен Данг Хой, Рожнов В.В. и др., 2017 [4]

[Source: Nguyen Dang Hoi, Rozhnov V. V. and etc., 2017 [4]]

бальные природоохранные ценности. Что касается высших растений, то сотни видов занесены в Красный список мира (IUCN), а также десятки млекопитающих в национальных парках Центрального нагорья. Типичный пример в национальном парке Бидуп - Нуй Ба, среди 1944 видов высших растений 132 вида с глобальной природоохранной ценностью; Из 111 видов млекопитающих до 70 видов (63\% от всех видов млекопитающих в парке) имеют глобальную защитную ценность (таблица 2).

За прошедшее время, несмотря на определенные достижения в области управления и эксплуатации природных ресурсов и охраны окружающей среды, сохраняются ограничения, которые являются основными препятствиями для устойчивого развития каждой провинции и всего региона. Центральное нагорье имеет большое значение по естественной географии, но исторический контекст создает слабости и проблемы в области управления ресурсами и защиты окружающей среды в период высокого развития: период индустриализации - модернизация страны. Это требование для Центрального нагорья не только сегодняшние дни, но и на много лет в будущем, когда необходимо анализировать ценность позиции этого региона.
При анализе лесных ресурсов и биоразнообразия, признаем, что в течение длительного времени леса и биоразнообразие Центрального нагорья управлялись и использовались в соответствии с моделями деревень и сел. Тем не менее, сразу после дня освобождения, чтобы быстро развиваться, мы вели себя неадекватно, что привело к серьезному сокращению лесных ресурсов и сокращению биоразнообразия, особенно во время до 1992 года. Параллельно с крупными программами и проектами, такими как 327 и 661 по защите, восстановлению и развитию лесов, в последнее время Партия и Государство представили новую политику и привлекали каждое домохозяйство для защиты леса. Многими деревнями установлены правила и конвенции по защите лесов. Это работа по соединению людей с природными ресурсами и окружающей средой в их собственном жилом пространстве. Кроме того, оплата полезности экосистем является одним из явных проявлений в управлении природными ресурсами и охране окружающей среды в регионе Центрального нагорья и между Центральным нагорьем и некоторыми провинциями Южного центрального побережья за выплаты гидроэлектростанций, компаний пользования водой лесовладельцами. 
В условиях изменения климата все сложнее и непредсказуемо становится проблема с водными ресурсами, вызывающая беспокойство не только у населения Центрального нагорья, Южного центрального побережья Вьетнама, но также у населения Лаоса и Камбоджи. Географическое положение, пространственное распределение, сезонная дифференциация климатических и водных ресурсов влияли и влияют на каждого человека. Однако, связь управления, эксплуатации, использования и защиты провинций Центрального нагорья, связь между Центральным нагорьем и Южным центральным побережьем, связь между Центральным нагорьем с соответствующими провинциями Лаоса и Камбоджи не была эффективной, ритмичной. Это более или менее повлияло на экономику, общество и окружающую среду, включая предотвращение и смягчение последствий стихийных бедствий, спасение людей, терпящих бедствие.

НЕКОТОРЫЕ РЕШЕНИЯ ПРОДВИЖЕНИЯ ПОТЕНЦИАЛА ГЕОПОЛИТИЧЕСКОЙ ПОЗИЦИИ ЦЕНТРАЛЬНОГО НАГОРЬЯ ДЛЯ ЭКОНОМИЧЕСКОГО РАЗВИТИЯ, УКРЕПЛЕНИЯ НАЦИОНАЛЬНОЙ ОБОРОНЫ И БЕЗОПАСНОСТИ, А ТАКЖЕ УПРАВЛЕНИЯ ПРИРОДНЫМИ РЕСУРСАМИ И ОКРУЖАЮЩЕЙ СРЕДОЙ

1. Повышение ценности пространственных ресурсов и не альтернативных форм: лесных, земельных, водных ресурсов и ресурса биоразнообразия Центрального нагорья. Сделать эти ценности движущей силой социально-экономического развития; создать пространство, чтобы связать потоки сырья и продуктов по направлению Восток - Запад. Привезти высококачественные источники рабочей силы из Южного центрального прибрежного региона и других регионов в Центральное нагорье; получить сырье и сельскохозяйственную и лесную продукцию из Центрального нагорья в Южный центральный прибрежный регион и Южный восточный регион Вьетнама. Следует обратить внимание на основные оси в планировании и модернизации транспортной системы, основанной на принципе обеспечения связи регионов: Вьетнам, Лаос, Камбоджа, Таиланд и Мьянма, основным выходом из которых является система международных морских портов на Южном центральном побережье.

2. Создание моделей управления природными ресурсами и охраны окружающей среды между провинциями, между Севером и Югом Центрального нагорья, между провинциями Центрального нагорья и Центральными прибрежными провинциями и Юго-восточными провинциями в соответствии с прилежащими местами и системами национальных дорог по направлению Восток-Запад. В частности, стоит отметить управление и сохранение лесных ресурсов, ресурсов биоразнообразия и водных ресурсов. Создать ряд межрегиональных природоохранных центров: Чу Зянг Син - Бидуп - Нуи Ба (пров. Лам Донг) - Хон Ба (пров. Кхань Хоа); Нгок Линь (пров. Кон Тум) - Нгок Линь (Куанг Нам); Тач Ньам (пров. Кон Тум) - Кон Чы Ранг (пров. Зя Лай), международный центр сохранения биоразнообразия в зоне соединения стран Индокитая в 3 провинциях Кон Тум (Вьетнам), Аттапеу (Лаос) и Натаракири (Камбоджа).

3. Организовать преемственную оборону между Центральным нагорьем и Южным центральным побережьем во внутренних и внешних связях (с прилегающими территориями). Планирование и проектирование ключевых компонентов оборонительных территорий на военном окружном и провинциальном уровне на основе преимуществ рельефа, лесов и человеческого фактора (этнические группы). Следует создать связь, непрерывную по пространству бассейна, а в системе пространство - этническое.

4. Развитие культурных связей и геополитического пространства, обеспечение национальной обороны и безопасности. Чем ближе внутренние культурные и политические связи, тем больше проталкивают внешние связи. Обратить внимание на связь между смежными уездами провинций Центрального нагорья и провинций Южного центрального побережья, особенно провинции, в которых одинаковые этнические группы. Это прочная основа политической системы, культурных ценностей и общечеловеческих ценностей, создающая специфическую геополитическую позицию для региона, устраняющая влияние нездоровых внешних факторов, непригодности всестороннего развития экономики, политики, укрепления национальной обороны и безопасности, эффективного управления природными ресурсами и окружающей средой для региона и страны.

\section{ЗАКЛЮЧЕНИЕ}

На протяжении длительного времени Центральное нагорье всегда сохраняет очень важную геополитическую позицию в борьбе с иностранными захватчиками, в строительстве и защите Вьетнама. Важность геополитической позиции региона определяется характеристиками геополитического пространства, геополитического регио- 
на и национального пограничного региона с Лаосом и Камбоджей.

Ценности природы и политического контекста региона Вьетнама, Лаоса и Камбоджи создали незаменимые ценности не только для Центрального нагорья, но и для окрестных районов Вьетнама, особенно связь Центрального нагорья - Южного центрального побережья с аспектами экономики, политики, национальной обороны - безопасности, природных ресурсов и окружающей среды.

Важным показателем геополитической значимости Центрального нагорья имеет индекс развития человеческого потенциала, который пока остается не самым высоким по сравнению с другими регионами Вьетнама [6].

Создание связи в области управления ресурсами, распространения материалов - потоков продуктов, создания преемственного положения в области обороны - безопасности и культурного пространства - этнической группы являются основными и важными вопросами для продвижения потенциала, ценности геополитической позиции Центрального нагорья в XXI веке и далеко в будущем.

\section{СПИСОК ЛИТЕРАТУРЫ}

1. Герасименко Т. И., Семенов Е. А. Экономико-географическое и геополитическое положение как интегральная пространственная категория // Вестник Оренбургского государственного университета, 2015, № 1(176), c. 156-161.

2. Карпов А. Л. Геополитические проблемы современной России // Известия Самарского научного центра Российской академии наук, 2008, № 1(10), с. 170-177.

3. Колосов М. А., Мироненко Н. С. Геополитика и политическая география. Москва, издательство Аспект Пресс, 2005. 479 c.

4. Нгуен Данг Хой, Рожнов В.В., Кузнецов А.Н., Лэ Суан Шон, Лэ Суан Дак, Нго Чунг Зунг. Сохранение, восстановление и устойчивое использование тропических лесных экосистем на основе изучения их структурно-функииональной организачии: национальные парки Центрального нагорья, периодический научный отчет по Э.1.2: 2012-2017, Ханой, 2017. 263 с.

5. Сирота Н.М. Геополитика. Санкт-Петербург, Издательский дом «Питер», 2006. 172 с.

6. Фи Хунг Кыонг, Ву Ван Ань Реальная обстановка и способы повышения индекса развития человеческого потенциала во Вьетнаме // Вестник Воронежского государственного университета. Серия География. Геоэкология, 2010, № 2, с. 7-11.

7. Naji S., Jawan J. A. Geopolitics of the Islam World and world leadership in the post-Cold War geopolitical developments // Transcience Journal, 2013, no. 1(4), pp. 1-12.

8. Slobodnikova O., Baar V. The Present Geopolitical and Geoeconomic Situation in Russia // Conference proceedings in Beyond Globalisation: Exploring the Limits of Globalisation in the Regional Context, Czech Republic. 2010, pp. 89-97.

9. Hoang Dinh Nhan. Defense cooperation of Vietnam with some countries in the world: Current situation and prospects. Journal of International Studies, 2016, no. 3(106), pp. 81-102. (In Vietnam.)

10. Le Duc An. Geomorphology of Vietnam: Structure - Natural Resources - Environment. Hanoi, Science and Technology Publishing House, 2012. 659 p. (In Vietnam.)

11. Le Duc An. Coastline of Vietnam: Structure and natural resources. Hanoi, Science and Technology Publishing House, 2015. 546 p. (In Vietnam.)

12. Nguen Dang Hoi. Political Geography: Theoretical issues and applied orientations in Vietnam. Proceedings of the 3rd National Conference on Vietnamese Studies. Ha Noi, 2008. pp. 622-636. (In Vietnam.)

13. Nguen Dang Hoi. Approaches in national border research. Journal of Hanoi National University of Education, 2014, no. 3, pp. 27-37. (In Vietnam.)

14. Nguen Dang Ho, Nguyen Cao Huan, Ngo Trung Dung, Pham Mai Phuong. Strategic geography and defense - security issues of the coastal zone of Danang - Khanh Hoa, Vietnam. Scientific Journal of Hanoi National University, 2015, no. 10, pp. 8-16. (In Vietnam.)

15. Pham Duc Trung. Lessons learned about choosing the direction and attack target in the Central Highlands campaign. Journal of Military Science, 2015, pp. 39-42. (In Vietnam.)

16. Pham Huu Thang. Separation and siege to mass destruction of enemies - a feature of military art in The General Offensive and Uprising of the Spring 1975. Journal of historical science, 2015, pp .66-71. (In Vietnam.)

17. Pham Quynh Phuong. The traditionally religious consciousness change of the ethnic minorities in the Central Highlands today. Journal of Religious Studies, 2014, no. 4(130), pp. 3-18. (In Vietnam.)

18. General Statistics Office of Vietnam. Statistical Yearbook 2019. Ha Noi, Statistical publisher, 2019. 128 p. (In Vietnam.)

19. Tran Duc Thanh, Nguyen Huu Cu, Tran Dinh Lan. Basic understanding of the location resources of the East Sea of Vietnam. Proceedings of the 30th anniversary of the establishment of Vietnam Academy of Science and Technology. Ha Noi, 2013, pp. 134-140. (In Vietnam.)

Конфликт интересов: Авторы декларируют отсутствие явных и потенциальных конфликтов интересов, связанных с публикацией настоящей статьи.

Поступила в редакичию 18.10.2019 Принята к публикации 02.06.2020 


\title{
Central Highlands of Vietnam. Geopolitical Assessment
}

\author{
Nguyen Dang Hoi ${ }^{1}$, Truong Quang Hai ${ }^{2}$ \\ ${ }^{I}$ Vietnamese-Russian tropical center, Vietnam (63 Nguyen Van Huyen, Nghia Do, Cau Giay, Ha Noi) \\ ${ }^{2}$ Hanoi State University, Vietnam (144 Xuan Thuy, Cau Giay, Ha Noi)
}

\begin{abstract}
The purpose is to analyze the main aspects that make up the geopolitical position of the Central Highlands, its importance and impact on economic development, strengthening national defense and security, management of natural resources and the environment. Methods and materials. For a geopolitical assessment of the Central Highlands, analytical methods of published materials were used. The geopolitical position of the Central Highlands is determined by the characteristics of the geopolitical space, the geopolitical region and the national border areas with Laos and Cambodia. The Central Highlands are closely connected with the surrounding areas, especially with the South Central Coast, to create unity that strengthens its geopolitical position not only in Vietnam, but also in Southeast Asia. Results and discussion. The creation of communication spaces between the interregion and the exregion, especially communications in the field of resource management, distribution of materials - product flows, the creation of a continuum in the field of defense security and cultural space - of an ethnic group are the main and important issues in economic development, strengthening national defense and security, and also in the management of the natural resources and the environment of this region. It also increases its importance as a geopolitical position in the 21 st century and far in the future. Conclusion. Throughout its history, the Central Highlands have always occupied a very important geopolitical position. Natural and ethnic values with a political context have created the indispensable values of the Central Highlands for economics, politics, national defense - security, natural resources and the environment. In order to further advance the value of the Central Highlands, it is necessary to establish spatial ties inside and out, establish a continuity in the field of defense - the security and cultural space of ethnic groups.
\end{abstract}

Key words: ethnic groups, Southern central coastal zone, defense area, Central Highlands, geopolitical position.

For citation: Nguyen Dang Hoi, Truong Quang Hai Central Highlands of Vietnam. Geopolitical Assessment. Vestnik Voronezskogo gosudarstvennogo universiteta. Seria Geografia. Geoekologia, 2020, No. 2, pp. 3-13. (In Russ.) DOI: ttps://doi.org/10.17308/geo.2020.2/2879

\section{REFERENCES}

1. Gerasimenko T. I., Semenov E. A. Jekonomiko-geograficheskoe i geopoliticheskoe polozhenie kak integral'naja prostranstvennaja kategorija [Economic-geographical and geopolitical position as an integral spatial category]. Vestnik Orenburgskogo gosudarstvennogo universiteta, 2015, no. 1 (176), pp. 156-161. (In Russ.)

2. Karpov A.L. Geopoliticheskie problemy sovremennoj Rossii [Geo-political issues of modern Russia]. Izvestija Samarskogo nauchnogo centra Rossijskoj akademii nauk, 2008, no. 1 (10), pp. 170-177. (In Russ.)

3. Kolosov M. A., Mironenko N.S. Geopolitika i politicheskaja geografija. [Geopolitics and political geography: A textbook for university students]. Moscow, Publ. Aspekt Press, 2005. 479 p. (In Russ.)
4. Nguyen Dang Hoi, Rozhnov V. V., Kuznesov A. N., Le Xuan Son, Le Xuan Dac, Ngo Trung Dung. Sohranenie, vosstanovlenie i ustojchivoe ispol'zovanie tropicheskih lesnyh jekosistem na osnove izuchenija ih strukturnofunkcional'noj organizacii: nacional'nye parki Central'nogo nagor'ja, periodicheskij nauchnyj otchet po E.1.2: 2012-2017 [Conservation, restoration and sustainable use of tropical forest ecosystems based on the study of their structural and functional organization: national parks of the Central Highlands, periodic scientific report of E.1.2.: 2012-2017]. Hanoi, 2017. 263 p.

5. Sirota N. M. Geopolitika [Geopolitics]. Sank-Peterburg, Publ. "Piter", 2006. 172 p. (In Russ.)

6. Phi Hung Cuong, Vu Van Anh Real'naya obstanovka i sposoby povysheniya indeksa razvitiya chelovecheskogo potentsiala vo V'etname [The real situation and ways to

(C) Nguyen Dang Hoi, Truong Quang Hai, 2020

E-mail: danghoi110@gmail.com

The content is available under Creative Commons Attribution 4.0 License. 
improve the human development index in Vietnam]. Vestnik Voronezskogo gosudarstvennogo universiteta. Seria Geografia. Geoekologia, 2010, no. 2, pp. 7-11. (In Russ.)

7. Naji S., Jawan J. A. Geopolitics of the Islam World and world leadership in the post-Cold War geopolitical developments. Transcience Journal, 2013, no. 1 (4), pp. 1-12.

8. Slobodnikova O., Baar V. The Present Geopolitical and Geoeconomic Situation in Russia. Conference proceedings in Beyond Globalisation: Exploring the Limits of Globalisation in the Regional Context, Czech Republic. 2010, pp. 89-97.

9. Hoang Dinh Nhan. Defense cooperation of Vietnam with some countries in the world: Current situation and prospects. Journal of International Studies, 2016, no. 3(106), pp. 81-102. (In Vietnam.)

10. Le Duc An. Geomorphology of Vietnam: Structure - Natural Resources - Environment. Hanoi, Science and Technology Publishing House, 2012. 659 p. (In Vietnam.)

11. Le Duc An. Coastline of Vietnam: Structure and natural resources. Hanoi, Science and Technology Publishing House, 2015. 546 p. (In Vietnam.)

12. Nguen Dang Hoi. Political Geography: Theoretical issues and applied orientations in Vietnam. Proceedings of the 3rd National Conference on Vietnamese Studies. Ha Noi, 2008. pp. 622-636. (In Vietnam.)

13. Nguen Dang Hoi. Approaches in national border research. Journal of Hanoi National University of Education, 2014, no. 3, pp. 27-37. (In Vietnam.)

Нгуен Данг Хой

кандидат географических наук, доцент, Директор Института тропической экологии, Российско-Вьетнамский тропический центр, г. Ханой, ORCID: https://orcid.org/ 0000-0001-6832-283X, e-mail: danghoi110@gmail.com

Чыонг Куанг Хай

кандидат географических наук, профессор, Ханойский государственный университет, г. Ханой, e-mail: haitq.ivides@gmail.com
14. Nguen Dang Ho, Nguyen Cao Huan, Ngo Trung Dung, Pham Mai Phuong. Strategic geography and defense - security issues of the coastal zone of Danang - Khanh Hoa, Vietnam. Scientific Journal of Hanoi National University, 2015, no. 10, pp. 8-16. (In Vietnam.)

15. Pham Duc Trung. Lessons learned about choosing the direction and attack target in the Central Highlands campaign. Journal of Military Science, 2015, pp. 39-42. (In Vietnam.)

16. Pham Huu Thang. Separation and siege to mass destruction of enemies - a feature of military art in The General Offensive and Uprising of the Spring 1975. Journal of historical science, 2015, pp .66-71. (In Vietnam.)

17. Pham Quynh Phuong. The traditionally religious consciousness change of the ethnic minorities in the Central Highlands today. Journal of Religious Studies, 2014, no. 4(130), pp. 3-18. (In Vietnam.)

18. General Statistics Office of Vietnam. Statistical Yearbook 2019. Ha Noi, Statistical publisher, 2019. 128 p. (In Vietnam.)

19. Tran Duc Thanh, Nguyen Huu Cu, Tran Dinh Lan. Basic understanding of the location resources of the East Sea of Vietnam. Proceedings of the 30th anniversary of the establishment of Vietnam Academy of Science and Technology. Ha Noi, 2013, pp. 134-140. (In Vietnam.)

Conflict of interests: The authors declare no information of obvious and potential conflicts of interest related to the publication of this article.

Received: 18.10 .2019

Accepted: 02.06.2020

Nguyen Dang Hoi

Cand. Sci. (Geogr.) Assoc. Prof. at the VietnameseRussian Tropical Centre, Hanoi, Vietnam, ORCID: https://orcid.org/0000-0001-6832-283X, e-mail: danghoi110@gmail.com

Truong Quang Hai

Cand. Sci. (Geogr.) Prof. at the Hanoi State University, Hanoi, Vietnam, e-mail: haitq.ivides@gmail.com 